\title{
Poeci, afekty \\ i miejsca wspólne, \\ czyli In Memory of My Feelings Franka O’Hary i Cover Andrzeja Sosnowskiego w perspektywie autotematycznej*
}

\footnotetext{
Praca finansowana ze środków budżetowych na naukę w latach 2018-2022, jako projekt badawczy w ramach programu „Diamentowy Grant” nr DI2017/008947: „Nowy autotematyzm? Metarefleksja w poezji polskiej po roku 1989”.
}

\section{Agnieszka Waligóra}

ORCID: 0000-0002-4316-9207

Andrzej Sosnowski jest jednym z najważniejszych i najbardziej wpływowych polskich poetów współczesnych. Jego twórczość stała się przyczynkiem do wielu istotnych krytycznoliterackich polemik, skupiających się najpierw wokół postmodernizmu, śmierci autora czy wyczerpania liryki, by później dostrzec zagadnienia takie jak podmiotowość, postsekularyzm czy polityczność i zaangażowanie. Urodzony w 1959 Sosnowski debiutował tomem Życie na Korei (1992); przez niemal trzydzieści lat aktywności twórczej spod jego pióra wyszło kilkanaście książek poetyckich, ale także zbiory esejów i poetyckich próz oraz liczne przekłady (tłumaczył między innymi Elizabeth Bishop, Rolanda Firbanka, Johna Ashbery'ego czy Arthura Rimbauda). Kontekst translatorski pozostaje dla interpretacji jego utworów oryginalnych nieobojętny: odnajduje się w nich liczne nawiązania do literatury zagranicznej, pojawiające się przy tym nie tylko na zasadzie postmodernistycznej zabawy tekstem. 
O Coverze Andrzeja Sosnowskiego - oraz jego relacjach z In Memory of My Feelings Franka O’Hary - napisano już sporo: utwory analizowane i porównywane były przez Tadeusza Piórę, Ryszarda Chłopka, Jacka Gutorowa i Ewę Rajewską ${ }^{1}$. Badacze wskazywali na rozmaite cechy, wyznaczniki i uwarunkowania quasi-gatunku coveru, podkreślając między innymi jego „przekładopodobność”, konieczną „pograniczność” (a więc istnienie na styku dwóch języków, dwóch poetyk), istotny kontekst postmodernizmu, który lokuje omawiany typ twórczości na tle kultury popularnej i sprzyja namysłowi nad ich intertekstualnością, możliwą parodystycznością czy (dekonstruowaną) kategorią nowości, zastępowaną przez pojęcie różnicy²; jak pisał Gutorow, cover to „utwór w nowej wersji, powtórzenie, lecz bynajmniej nie takie samo”3.

Choć przywoływane w tytule rozprawy liryki nie są zatem ani odbiorcy nieznane, ani nieobecne w krytyce, wydaje się, że wciąż nie powiedziano o nich ostatniego słowa. Przede wszystkim więc - można zastanawiać się nad niezwykle istotnym w wypadku dzieł określanych jako postmodernistyczne kontekście autotematycznym. W perspektywie metarefleksji utwory Sosnowskiego i O'Hary wchodzą ze sobą w niezwykle ciekawą relację, kontrastującą nieco - lub wręcz przeciwnie, paradoksalnie łączącą - permanentnie dyskutowaną konstrukcję nowoczesnego podmiotu jako bytu, któremu jednocześnie chce się przyznawać nadrzędną funkcję spajania doświadczeń, jak i ustawicznie wyraża zwątpienie w jej szanse, z postmodernistycznym zanurzeniem w tekście i zanegowaniem istnienia rzeczywistości innej niż znakowa. Można jednak na przywoływane dzieła spojrzeć także z perspektywy ich poetyki, zadając pytanie o jej tytułową „międzyobecność” - a zatem o to, jak na styku omawianych wierszy nawiązuje się stosunek nie tyle dialogu czy odpowiedzi, a właśnie swoistej współpracy. Ewentualne odpowiedzi na drugą z postawionych kwestii wynikać będą przy tym oczywiście z pierwszej: autotematyczne wątki Coveru i In Memory of My Feelings dostarczyć mogą bowiem ciekawych pomysłów interpretacyjnych dotyczących zwłaszcza tekstu „pochodnego" (o ile uruchomić starą przekładoznawczą - i nie tylko - retorykę dzieła oryginalnego i naśladowczego, źródła i kopii).

Objętość i poziom skomplikowania przywoływanych dzieł, z których każde stanowi kilkustronicowy (i przy tym - wielopiętrowy) poemat o licznych odniesieniach kulturowych i symbolicznych, wyklucza oczywiście możliwość rzetelnej analizy na przestrzeni jednego artykułu, zwłaszcza jeśli miałoby to być badanie pozostające w miarę możliwości blisko tekstów, cechujących się sporym hermetyzmem i ponadto otwierających liczne drogi interpretacji kontekstowej. Wypadnie więc pozostać jedynie przy garści wstępnych uwag, które mogą posłużyć jako przyczynek do ponownej refleksji nad omawianymi poematami oraz istotną rolą obecnych w nich wątków autotematycznych.

\footnotetext{
${ }^{1}$ Zob. też Tadeusz Pióro, „Czas to biurokracja, którą tworzą wszyscy”, w Lekcja żywego języka: o poezji Andrzeja Sosnowskiego, red. Grzegorz Jankowicz (Kraków: Zielona Sowa : Studium Literacko-Artystyczne przy Instytucie Polonistyki Uniwersytetu Jagiellońskiego, 2003); Ryszard Chłopek, „Kogo śmieszy «Cover»?”, w Lekcja żywego języka: o poezji Andrzeja Sosnowskiego, red. Grzegorz Jankowicz (Kraków: Zielona Sowa : Studium LiterackoArtystyczne przy Instytucie Polonistyki Uniwersytetu Jagiellońskiego, 2003); Jacek Gutorow, „Kilwater”, w Urwany ślad: o wierszach Wirpszy, Karpowicza, Różewicza i Sosnowskiego (Wrocław: Biuro Literackie, 2007); Ewa Rajewska, „Kariera coveru”, w Kultura w stanie przekładu: translatologia - komparatystyka - transkulturowość, red. Włodzimierz Bolecki i Ewa Kraskowska (Warszawa: Fundacja Akademia Humanistyczna : Instytut Badań Literackich PAN. Wydawnictwo, 2012).

${ }^{2}$ Zob. Rajewska, „Kariera coveru”, 328-29.

${ }^{3}$ Gutorow, „Kilwater”, 190.
} 
Jak mogłaby brzmieć wyjściowa teza interpretacyjna, dotycząca ogólnego wydźwięku obu tekstów (stawiana przy założeniu, że Cover Sosnowskiego jest coverem In Memory of My Feelings O’Hary, a zatem wchodzą one ze sobą w szeroką relację intertekstualnego i międzyjęzykowego dialogu $\left.\mathrm{u}^{4}\right)$ ? Zapewne jedną z najoczywistszych propozycji byłoby następujące rozróżnienie: In Memory of My Feelings jest, mówiąc ogólnie, utworem poświęconym doświadczeniu oraz podmiotowości; sugerują to rozmaite elementy składowe wiersza, takie jak obecność licznych „naked selves” bohatera, z których każde poszczególne „self” ma własne przygody w tym szczególnie istotna wydaje się postać węża („,serpent”), opis percepcji i przeżyć którego zastępuje w pewnym momencie perspektywę człowieka (czy też swoistej upersonifikowanej postaci, opisywanej we fragmencie „my quietness has a man in it, he is transparent"5), wielokrotna obecność nazw konkretnych emocji i stanów („Manfred climbes to my nape,/speaks, but I can't hear him,/I’m too blue") oraz multisensoryczność (opis uczuć przekładany na zmysłowy odbiór ciepła i zimna, a także struktury, materialności konkretnych przedmiotów, jak we fragmencie: „though in winter/they are warm as roses, in the desert/taste of chilled anisette"). Na taki typ lektury O’Hary nakierowuje także znajomość jego twórczości, cechującej się zanurzeniem w codzienności, doświadczeniowości, prywatności i konkrecie osobistego przeżycia. W zasadzie jednak sama lektura tytułu wyraźnie profiluje interpretację dzieła: obok podmiotowej (prywatnej lub kolektywnej) pamięci pojawia się w nim także znaczące odniesienie do „moich uczuć” („my feelings”). Nie tylko zatem skupia to uwagę na emocjonalnym charakterze utworu, ale i wyraźnie podkreśla rolę ich przynależności do określonej postaci (człowieka? węża? podmiotu o nieustalonej, podatnej na transformacje tożsamości?). Warto zwrócić także uwagę na dedykację, jaką poeta opatrzył swój wiersz - Grace Hartigan była znaną malarką ekspresjonistyczną; nie tylko wzmacnia to „emocjonalną” interpretację utworu, ale i wnosi istotny kontekst intersemiotyczności, tak dla autora istotnej ${ }^{6}$.

Zgoła inaczej rysuje się tu wstępna interpretacja Coveru: jego tytuł nie dość, że enigmatyczny (nie odsyła bowiem bezpośrednio do treści utworu, jak to ma miejsce w przypadku O’Hary; nie sugeruje nawet, czego coverem będzie, co w gruncie rzeczy na gruncie coverowym niespotykane - zarówno w kulturze popularnej, chętnie posługującej się coverem w zakresie muzyki, jak i praktyce literackiej, o czym świadczy lista przywoływanych przez Gutorowa tytułów składających się na swoisty korpus przykładów owego quasi-gatunku7), to odsyłający jedynie do kategorii genologicznych, teoretycznych i semiotycznych. Tytuł wiersza Sosnowskiego nie mówi zatem, o czym jest (ani do czego się odnosi), ale czym jest, przenosząc punkt ciężkości analizy z treści i problematyki na zagadnienia rodzajowe, a zatem - tekstowe. Wyjaśnienie, czego coverem jest Cover, następuje dopiero w jednej z końcowych partii utworu, co swoją drogą także w praktyce coverowania dość niespotykane. Wiersz odsłania jednak mechanizm własnego powstania w samej swej tkance, co - wspomagane przez jego treść, zwłaszcza zaś eksplicytnie metarefleksyjną część drugą - czyni go utworem ściśle autotematycznym, prob-

\footnotetext{
${ }^{4}$ Rajewska, „Kariera coveru”, 328-29.

${ }^{5}$ Wszystkie cytaty z poematu O’Hary pochodzą z wydania: Frank O’Hara, „In Memory of My Feelings”, w The Collected Poems of Frank O'Hara, red. Donald Allen (Berkeley, Calif.: Univ. of California Press, 1995), 252-57.

$\mathrm{Z}$ uwagi na istotną wagę różnicy języków polskiego i angielskiego w omawianych utworach wykorzystuję cytaty pochodzące jedynie $\mathrm{z}$ oryginału, nie zaś z polskiego przekładu.

${ }^{6}$ Zob. Marjorie Perloff, Frank O'Hara: Poet among Painters (Chicago: Univ. of Chicago Press, 1997).

${ }^{7}$ Zob. Rajewska, „Kariera coveru”, 324. Badaczka przytacza tam przykłady podane przez Gutorowa podczas warsztatów literackich.
} 
lematyzującym zarówno byt własny, jak i swej tekstowej inspiracji, źródła czy odwołania. W najogólniejszym i upraszczającym rozumieniu In Memory of My Feelings jest więc poematem o podmiocie i jego doświadczeniu, zaś Cover - tekstem o innym tekście; tekstem o tekstowości. Zawiązywałoby to par excellence sytuację dialogu: znakocentryczny postmodernista Sosnowski dyskutuje więc $z$ emocjonalnym modernistą O'Harą ${ }^{8}$, Sosnowski pozostaje więc „typowym” Sosnowskim, a O’Hara - „typowym” O’Harą. Tym samym - wszak oba utwory są przy tym wyraźnie samotematyczne - otrzymujemy nie tylko doskonałe potwierdzenie (dawno obalonych) analitycznych etykiet dotyczących twórczości obu poetów, ale i podział metarefleksji na tę skupioną na podmiocie (twórczym) oraz produkcie (tworzenia): podział o idealnie czystych granicach.

Sprawę komplikuje jednak nie tylko fakt, że stereotypowe przekonania o autorach zostały już wielokrotnie zdekonstruowane (o Sosnowskim jako melancholiku oraz podmiotowych i doświadczeniowych aspektach jego twórczości pisały między innymi Karolina Felberg czy Alina Świeściak ${ }^{9}$, zaś jednostronności odczytania poematu O’Hary zdecydowanie zaprzecza interpretacja Pióry ${ }^{10}$ ). Choć Cover rzeczywiście pełny jest odwołań do innych tekstów literackich (i nie tylko), większość z nich cechuje się dość sporą emocjonalnością. "Chodzę i pytam./ Już trzydzieści lat temu bawiłem, przejazdem w Małkini (...)” oraz „chodzę i pytam, brnę/po uszy w bagnie, żeby odzyskać kotwicę"11 stanowią odniesienia do słynnej frazy Rafała Wojaczka („chodzę i pytam: gdzie jest moja szubienica”), mogącej być zarówno nawiązaniem do samobójczych skłonności poety, jak i pytaniem o przeznaczenie i sens egzystencji w ogóle. Fragmenty ze Snu o Warszawie Czesława Niemena lokują zaś problematykę przywiązania do miejsca (w wersji Sosnowskiego - być może wyrugowania, poszukiwania „własnej drogi”) oraz emocji związanych z konkretną przestrzenią.

W czwartej części poematu pojawia się także znaczący obraz: nawał znaków długiego wiersza porównany zostaje z desantem stonki na polską plażę („stonka z miejsca przechodzi do ataku jak wiersze Franka O’Hary./Co to za poemat, długi jak przemarsz dywizji?/Patrzę/i naturalnie w dłoni wyrasta mi butelka z naftą, kiedy ten desant przenika/faszynowe płotki, włazi na wydmy i niknie w głębi lądu za ochronną kosówką/mrowiem wersów «In Memory of My

8 O twórczości O’Hary w kontekście modernizmu pisał T. Pióro: Tadeusz Pióro, Frank O’Hara and the Ends of Modernism (Warsaw: University of Warsaw. Institute of English Studies, 2013).

${ }^{9}$ Karolina Felberg, „Melancholia i ekstaza”: projekt totalny w twórczości Andrzeja Sosnowskiego (Warszawa: Instytut Badań Literackich PAN, 2010); Alina Świeściak, „Melancholia ponowoczesna. Andrzej Sosnowski”, w Melancholia w poezji polskiej po 1989 roku (Kraków: Towarzystwo Autorów i Wydawców Prac Naukowych Universitas, 2010). Problem podmiotowości w tej poezji pozwalam sobie - z racji ogromnego skomplikowania i licznych głosów krytycznych - pominąć, akcentując jednak, że ta pozornie typowo „postmodernistyczna” twórczość nie jest wcale od intrygujących przejawów „Ja” wolna i skupiając się wyłącznie na tym, co możliwe do odnalezienia na poziomie omawianego tekstu. $Z$ podobnych przyczyn zmuszona jestem pominąć zagadnienie modernistyczności Sosnowskiego czy bliższe przyjrzenie się kategorii mimesis.

${ }^{10}$ Badacz zauważa więc, że choć metodą O’Hary jest pisanie w stylu „jestem tym, jestem owym”, to „niektóre z historycznych wydarzeń, które O’Hara przywołuje, mają kampowe zabarwienie, choć większość z nich - związanych z polityką i konfliktami zbrojnymi - pojawia się w kontekście rozmaitych zmian w historii sztuki i smaku”, dalej pisząc, że „w swojej analizie poematu Lytle Shaw zwraca uwagę na typowe dla kampu upodobanie do kopii - oryginał przestaje się liczyć”. Tadeusz Pióro, „Czytanie poematów O’Hary”, Literatura na Świecie., nr 9-10 (2015): 85. Ochładza to nieco częste „emocjonalne”, „barbarystyczne” analizy (czy może raczej - świadectwa recepcji) poezji nowojorczyka, wskazując na jej silnie samoświadome - zarówno „podmiotowo”, jak i „literacko” - wydźwięki.

${ }^{11}$ Wszystkie cytaty z poematu pochodzą z wydania: Andrzej Sosnowski, „Cover”, w Dożynki 1987-2003 (Wrocław: Biuro Literackie, 2006), 117-22. 
Feelings»!"). Tym samym wprowadzone już przez statek (na którego Sosnowski podmienił węża) wątki marynistyczne zyskują ciekawy kontekst kolonizacji - amerykanizacji: ojczyzną poetów, którymi się autor Coveru fascynuje, są wszak położone za oceanem Stany Zjednoczone, a mrowie wersów zyskuje paralelę z mrowiem owadów - elementu importowanego (zrzuconego na plażę przez marines), zalewającego polskie ziemie. Sprawia to, że - po pierwsze - statek możemy rozumieć nie tylko w odwołaniu do kulturowej symboliki oraz indywidualnego, autorskiego „toposu” (dość wspomnieć o fascynacjach Sosnowskiego Rimbaudem oraz całym tomie Trawers, zbierającym zresztą przedruki z wydań wcześniejszych), ale i jako swoistą metaforę medium między przestrzeniami, na przykład przestrzeniami dwóch języków. Pewne odwołanie do owej „pośredniczącej” figury stanowić może pierwsza część Coveru, w której czytamy: „Kapitan Nemo staje obok mnie/i coś tłumaczy, ale ja nie słyszę,/jestem niewytłumaczalny" (będącej dokładnym formalnym odbiciem cytowanego już fragmentu z O’Hary: „Manfred climbes to my nape”).

Kategorie niewytłumaczalności, wykorzenienia, zamknięcia (oddane w Coverze także za pomocą takich scen jak ta, w której podmiot mówi: „czasami bez tlenu/schodzę w lazurowy odmęt/i patrzę na świat przez panoramiczne owadzie okno") zyskują więc sąsiedztwo zagadnień zgoła innych - mrowie wersów poematu odnosi się zatem nie tylko do przytłoczenia rodzimej przestrzeni (czy - po prostu - przytłoczenia podmiotu) nawałem znaków, w których nie może się odnaleźć (i dlatego wiecznie gubi ślady, a wiersz nigdy nie wraca do domu), ale i do aktywności żywych istot. Znaki skojarzone z ruchliwymi owadami lokują nie tylko problematykę nieskończonej semiozy, ale są też skojarzeniem ze światem zwierząt. Tym samym utwór traci wydźwięk czysto tekstualny, stając się swoistą mieszaniną przypisywanej często Sosnowskiemu znakocentryczności i - właściwej między innymi O’Harze - afektywności.

Podobnie jest zresztą z drugą częścią poematu, w której Sosnowski pisze: „Moje dziecko, moje «ja», zdeklasowani klasycyści i klasycy. Mój/«smutek tropików» beztroski jak wiatr,/zanim jeszcze wylądowałem na Korei/pajęcza arabeska pleśni na końcu języka/pękająca jak siateczka naczyń nośnych/dla krwi uciekającej na wszystkie strony/zapisane nieodpowiedzialnymi znakami”. Bezpośrednie odwołanie do procesu pisania nie zanurza metarefleksji całkowicie w zagadnieniach tekstualności (na przykład rozmywając ją do szeregu intertekstualnych nawiązań i gier), ale sytuuje ją w kontekście „ja” oraz „mojego (jego) dziecka”, „mojego smutku tropików”. Podporządkowanie sobie wielu elementów wiersza (kilkukrotne podkreślanie ich przynależności do „mnie”, nawet gdy odniesieniem „smutku tropików” jest nie Andrzej Sosnowski, a raczej Claude Lévi-Strauss) upodmiotawia wiersz, przydając mu ponownie afektywności. Walor konkretu, tak istotnego u O'Hary (być może niekoniecznie w omawianym poemacie, ale w wielu innych tekstach, często chociażby adresowanych do przyjaciół poety i poruszających kwestię ich prywatnych relacji), przynosi natomiast początek części piątej, gdzie czytamy: „nie chciałbyś tego zrobić, Piotrze?/Jeszcze tylko kwadrans szkunera./On płynie tak bardzo daleko./Sens,/serce/arktycznego konwoju, jeśli to move is to love". Pod imieniem Piotra trudno nie rozpoznać Piotra Sommera, tłumacza poezji amerykańskiej, który wydał słynny zbiór przekładów Franka O’Hary (a kilkanaście lat później opublikował na łamach "Literatury na Świecie” tłumaczenie Pamięci moich uczući ${ }^{12}$ ). Cytowane wersy cechuje zresztą interesująca sentymentalność („on płynie tak bardzo daleko”),

\footnotetext{
${ }^{12}$ Frank O’Hara, „Pamięci moich uczuć”, tłum. Piotr Sommer, Literatura na Świecie., nr 9-10 (2015): 75-82.
} 
zaś swoista prośba do Piotra, by „coś” zrobić, nie tylko jest ciekawym przykładem tematyzowania życia literackiego (czy całej literackiej infrastruktury) na przestrzeni poezji, ale i może jawić się jako swoiste „wytłumaczenie siebie”.

Poprzednie wersy - zakończenie części czwartej - brzmią bowiem tak: „Wyglądają na roboli wyobraźni, te chrząszcze,/i przynoszą mi szum fal, w których zakochałem się jako wisielec". Wyznanie, że poszukujący przeznaczenia podmiot zakochał się w szumie fal (tych, które omywają plażę, na jakiej marines przeprowadzili desant stonek-znaków), jest zatem zarówno kolejnym momentem, w którym ujawniony zostaje afekt; być może jest to także całkiem proste wyznanie, że podmiot poczuł ów afekt do mrowia wersów poematu In Memory of My Feelings, sam zaś nie może (nie chce? nie umie? nie zajmuje się tym?) przetłumaczyć go na język polski. Pozostaje mu więc prosić Piotra. Taka interpretacja - rzecz jasna upraszczająca, sprowadzająca niezakorzenionego Sosnowskiego do poziomu prostych rozpoznań interpretacyjnych - tłumaczyłaby, dlaczego Sosnowski poemat poddał coveryzacji: ponieważ przetłumaczenie go zostawił Piotrowi, sam zaś poddał się - zakochaniu?, tłumacząc jedynie początkowe wersy drugiej części poematu, co znaczące - ujęte w przestrzeni Coveru w nawias („«martwi są na łowach - żywi zwierzyna łowna»", w oryginale „the dead hounting/and the alive, hounted").

Wyznanie emocjonalnego stosunku do tekstu - zabarwionego jednak ironią, wszak tekst O’Hary porównany zostaje do armii atakujących stonek - swoiście dyskutuje też z podkreślaną przez badaczy dialogicznością relacji między Coverem a In Memory of My Feelings. Ową dialogiczność zapewniać miałyby liczne zmiany i podmiany, których Sosnowski dopuścił się na przestrzeni tekstu, a więc przede wszystkim obecność szkunera zamiast oryginalnego węża ${ }^{13}$. Chociaż autor Coveru - przynajmniej w początkowych partiach tekstu - pozostaje całkowicie wierny strukturze poematu O’Hary, precyzyjnie oddając rozpiętość wersów i akcentację, wprowadza wiele znaczących modyfikacji. Rozpoczynają się one już w pierwszych słowach utworu, w których oryginalne „my quietness has a man in it, he’s transparent/and he carries me quietly, like a gondola, through the streets” zostaje zastąpione przez: „mój niepokój ma przy sobie broń, ona nie jest biała/i towarzyszy mi w spokojne dni jak lotniskowiec”. Zawarte w In Memory of My Feelings „he” („man”) zostaje zastąpione przez „nią” - broń; w dalszej części pierwszej strofy Sosnowski pisze także „ona jest funkcjonalna, jak eskadra i eskorta, jako desant” (w miejsce „he has several likenesses, like stars and years, like numerals".

Znaczące jest oczywiście odejście od podmiotowego „man” (oraz „me”, „selves” itd.) na rzecz pierwotnie odpersonalizowanej „broni”, „statku” czy „konwoju”. Kwestia podmiotowości w obu utworach jest jednak znacznie bardziej skomplikowana, co w tym miejscu skomentować można jedynie poglądowo. Bohater-podmiot In Memory... jest więc - co oczywiste - wciąż zanurzony w konstrukcjach modernistycznych, waha się zatem między spoistą, esencjalną tożsamością racjonalnego „Ja” oraz labilną mnogością zmiennych wcieleń. Zauważmy jednak, że - dzięki autotematycznej samozwrotności, ujawnionej już w pierwszej strofie poematu podmiot ten czyni tu krok w stronę niemodernistycznych koncepcji „Ja”.

\footnotetext{
${ }^{13} \mathrm{Na}$ elementy polemiczne wskazuje na przykład: Pióro, „Czytanie poematów O’Hary”, 107-8.
} 
Badająca formy samozwrotne w literaturze nowoczesnej Roma Sendyka zauważa, że sama idea „Ja” jest w pewnym sensie nietrafiona: zastąpić może ją natomiast metarefleksyjne „self” („siebie”), które będzie nie tylko pewnym krokiem w stronę dekonstrukcji antropocentrycznej definicji podmiotu (zaimek „siebie”, choć nie w formie znakowej, jest bowiem aplikowany także u innych bytów - kierowanych imperatywem, by „ochronić siebie”, „zadbać o siebie" itd.). To właśnie owo wytworzone w procesie autorefleksji nad-Ja (to, które myśli „o sobie” - myśli „siebie”, a także dystansuje się wobec swoich temporalnych i przestrzennych, konkretnych i zmiennych „Ja”) jest instancjsą spajającą doświadczenia podmiotu ${ }^{14}$. U O'Hary sprawa ta jest nieco bardziej skomplikowana, zaznaczmy jednak, że kiedy pisze on: „my quietness has a man in it, he's transparent/and he carries me quietly, like a gondola, through the streets", rysuje sytuację całkiem podobną: mówi zatem o uprzednim, bezpośrednim doświadczeniu czy uczuciu „my quietness”, które ma w sobie „kogoś” („a man”) - pewne medium mnogich, czujących „Ja”, które niesie je przez świat. Kruche tożsamości owego „Ja” wymagają przy tym obrony, której dokonuje owo „nad-Ja”, zamykające w sobie także cielesną figurę bohatera (tę niosącą go niczym gondola), co swoją drogą umacnia także materialno-duchowy dualizm istnienia.

Nieco inaczej jest natomiast u Sosnowskiego, u którego brakuje bezpośrednich, emocjonalnych ewokacji „Ja” - nie znaczy to jednak, że jest ono nieobecne ${ }^{15}$. Z całą pewnością Cover opisuje także pewną przygodę podmiotu (co potwierdza ciągłe podkreślanie pierwszoosobowej „narracji”: „schodzę”, „patrzę” itd.), być może też - przygodę pewnej zbiorowości (pojawiający się kilkukrotnie „konwój” jest wszak określeniem pewnej grupy). Zamiast swoiście „bezpiecznej”, uczuciowej relacji, obecnej w poemacie O’Hary przynajmniej na początku, konsekwentnie opisuje natomiast niepokój, brak zakotwiczenia („niekonwencjonalny teatr wojny”, „twierdza wysadzona w platynowe powietrze”, „wymowny wrak sterczący u wejścia do portu" itd.). Można zaryzykować zatem stwierdzenie, że bohaterowi Coveru - w przeciwieństwie do bohatera In Memory of My Feelings - brakuje „spokojnej gondoli”: medium, które mogłoby scalić jego byt. Pozostaje mu jedynie szkuner (wrak, statek bez kotwicy), odnoszący się do licznych tekstów kultury, z których jednym z istotniejszych byłby może Statek pijany Arthura Rimbauda.

Interesująco wpływa na interpretację „podmiotowości” także samo motto, zaczerpnięte z Augusta Strindberga: „na witrynie zakładu widzę wymalowane moje inicjały: A.S., unoszące się na srebrzystobiałym obłoku, a ponad nimi łuk tęczy". Analogia między inicjałami Sosnowskiego i Strindberga problematyzuje tu kwestię autorstwa, ale i istnienia "Ja” w ogóle - czy Strindberg patrzy rzeczywiście na swoje inicjały, skoro są to jednocześnie inicjały Sosnowskiego? Czy imię - a raczej skrót imienia - rzeczywiście identyfikuje podmiot, skoro noszą je także inne podmioty? Czy znaki mówią prawdę o rzeczywistości, skoro - po pierwsze - można pod nie podstawić inne desygnaty, a po drugie - rozciąga się za nimi świat, który trudno sprowadzić do słów (obłok, tęcza)? Czy cokolwiek da się sprowadzić do tekstu - podmiot do imienia czy inicjałów, zjawiska do nazwy, przeżycie do wiersza - a może

\footnotetext{
${ }^{14}$ Por. Roma Sendyka, Od kultury ja do kultury siebie: o zwrotnych formach w projektach tożsamościowych, 2015.

${ }^{15} \mathrm{O}$ emocjonalności całego tomu Konwój. Opera wspominał T. Pióro, pisząc, że: " "operowość» Opery polega na wtłoczeniu wielkiej dawki patosu do sytuacji codziennych, banalnych, a zarazem ostatecznych, to znaczy zawsze dotykających śmierci”. Pióro, „Czas to biurokracja, którą tworzą wszyscy”, 114.
} 
tekstem jest wszystko, problemem jest zaś kwestia interpretacji: jeśli A.S. to nie tylko August Strindberg, ale i Andrzej Sosnowski, to czy ma znaczenie, kim jestem „Ja”, skoro i tak nie istnieje jednoznaczność? Zasadniczo oba poematy opisują więc pewne problemy z własną podmiotowością oraz jej relacją ze światem ${ }^{16}$, każdy czyni to jednak w nieco odmienny sposób; warto jednak zauważyć, że prosta konstatacja o modernistyczności (nowoczesności) O’Hary oraz postmodernistyczności (ponowoczesności) Sosnowskiego napotkałaby na wiele komplikacji, z których jedną byłaby właśnie owa wskazana nieokreśloność podmiotu amerykańskiego poety.

Pełen opis wszystkich zmian, których dokonuje względem poematu O’Hary Cover, wymagałby napisania odrębnej rozprawy. Zauważmy natomiast jeszcze, że Sosnowski konsekwentnie posługuje się metaforyką (symboliką, sztafażem) marynistycznym (nie tylko statek, ale i morze, kotwica, ryby itd.), podczas gdy w In Memory of My Feelings znaczący jest kontrapunkt między wijącym się wężem (momentalnie nasuwającym skojarzenia z przywiązaniem do ziemi - wszak według Biblii Szatan ukarany został za swe winy skazaniem na wieczne pełzanie) a przestrzeniami powietrznymi, górskimi czy wręcz kosmicznymi („I rise into cool skies/and gaze at the imponderable world with the simple identification/of my colleagues, mountains”, „one of me/flutters up from the center of the track amidst the pink flamingoes”, figura księżyca pojawiająca się w wersie „a flaking moon drifting across the muddied teeth”). Co jednak znaczące, ostatni wers pierwszej części poematu („,and presently the aquiline serpent comes to resemble the Medusa") przynosi postać jednej z głów Gorgony - co warte nadmienienia, według mitologii jedynej śmiertelnej z trzech potwornych bogiń.

Meduza - to bóstwo morskie. Dla węża z poematu O’Hary przestrzeń wodna jest najbardziej przerażająca - ziemia, choć także pełna zagrożeń (i brudu, lokowanego dzięki odniesieniom do błota), jest jego królestwem; przestrzenią wymarzoną jest natomiast niebo. Sosnowski skupia się właśnie na tym, co w In Memory of My Feelings wspomniane negatywnie - tym samym cover staje się nie odwróceniem, a swoistym uzupełnieniem oryginalnego utworu. Podobnie ma się sprawa z innymi wspomnianymi elementami. Podmiot Sosnowskiego - ten, który wciąż chodzi i pyta, gdzie może zarzucić swą kotwicę - nie czuje spokoju (jak tłumaczyć można wieloznaczne słowo "quietness", konotujące również ciszę, milczenie, łagodność czy wycofanie), ale właśnie niepokój. Broń, o której pisze dalej autor Coveru, pojawia się i u O’Hary, we fragmencie „my quietness has a numer of naked selves,/so many pistols I have borrowed to protect myselves/ from creatures who too readily recognize my weapons/and have murder in their heart!"17.

Wytworzone w In Memory... „self”, samozwrotna instancja spajająca nietożsamy podmiot (czy raczej podmiot o wielu figurach), zdaje sobie sprawę z kruchości i bezbronności swych ruchliwych „selves”, stąd wypożyczanie mnogich broni - spokojne i ciche, przezroczyste „nad-Ja”,

\footnotetext{
${ }^{16}$ Refleksję nad autorstwem i podmiotowością w Coverze - czy raczej wątpliwości względem możliwości takiej refleksji - przejawiał już Gutorow, Zob. Gutorow, „Kilwater”, 189-90.

${ }^{17}$ Podobną intuicję - w sprawie polemiczności, ale i łączliwości obu utworów, podobieństw w zakresie obrazowania, ale z pewną dozą przewrotności - wykazywał R. Chłopek, zob. Chłopek, „Kogo śmieszy «Cover»?”, 169. Wydaje się jednak, że można dyskutować z tezą, iż „różnice przebiegają w sposób niejednorodny i charakter diametralny przyjmują jedynie tam, gdzie mowa jest o samym podmiocie lub jego jaźniach, czyli o tym, co osobiste i o czym mówić najtrudniej”. Być może właśnie „lekcja afektywnej poezji” pozwala tu na otwarcie i wytworzenie miejsc wspólnych, a nie prowadzi do sprzeczności.
} 
które niczym gondola niesie w sobie „Ja” podmiotu oraz wszystkie jego multiplikacje, nie przejawia naturalnej agresji: przemoc jest dla niego czymś obcym. Zgoła inaczej rzecz się ma w Coverze, w którym potrzeba eskadry i eskorty: Cover jest bowiem poematem opartym na niepokoju - warto zauważyć, że ów znakocentryczny Sosnowski rozpoczyna utwór silnym afektem, zaś emocjonalny O’Hara - wyciszeniem. Gondola, do której porównana zostaje „cichość” podmiotu, zyskuje paralelę z użytym przez Sosnowskiego szkunerem - statkiem, który nie kojarzy się już tak bardzo z przyjemną wycieczką. W istocie więc Sosnowski nie tyle dialoguje z In Memory of My Feelings, ale w pewien sposób remiksuje wykorzystane w nich elementy, czym wpływa na ich rekontekstualizację. Zasadniczo nie zmienia jednak najogólniejszych kategorii obrazowania - na przykład ziemia i góry, choć zastąpione przez morze, tak jak woda są określeniami przestrzeni; statek zaś, choć zasadniczo różny od węża, podobnie jak on przykuty jest do pewnej powierzchni, po której przemieszcza się ruchem posuwistym. Są to oczywiście analogie dalekie; podobne relacje odnaleźć można jednak na przestrzeni całego utworu, a więc wskazywane u O'Hary „my father, my uncle,/my grand-uncle and the several aunts. My/grand-aunt dying for me, like a talisman, in the war” oddane zostaje jako „moje dziecko, moje «ja»,/zdeklasowani klasycyści i klasycy. Mój/«smutek tropików», beztroski jak wiatr”. Oba fragmenty wykorzystują określenia „rodzinne” - u O’Hary dosłowne (ojciec, wuj, ciotki), u Sosnowskiego zaś - sugerujące raczej rodowód literacki (znamienne, że w dalszej części Coveru „jego dziecko” sportretowane zostaje jako juror konkursu recytatorskiego).

Choć ponownie lokowałoby to wyraźne rozgraniczenie na autotematyzm „podmiotowy” (widoczny u O’Hary) i „tekstowy” lub „literacki” (wyraźny u Sosnowskiego), warto zauważyć, że właśnie owa tekstualność Coveru - i twórczości jego autora w ogóle - zostaje swoiście rozbita właśnie przez przejęcie elementów upodmiotawiających, czy może raczej: interpretujących podmiotowość w kategoriach tekstowych - lub tekst w kategoriach podmiotowych. Uprawnia to do postawienia hipotezy, że poetyka wykorzystana (czy wytworzona) przez Sosnowskiego na przestrzeni omawianego poematu jest $\mathrm{w}$ istocie interpoetyką - $\mathrm{z}$ kilku równoważnych względów.

Po pierwsze więc, znacząca jest oczywiście sytuacja różnicy języków: angielskiego In Memory of My Feelings (które, podkreślmy, wówczas jeszcze nie funkcjonowało w przekładzie na język polski) oraz rodzimego Coveru (którego tytuł jest, co bardzo istotne, anglojęzyczny). Wykorzystanie struktury czy układu formalnego utworu O’Hary (przede wszystkim więc rozczłonkowania na wersy i strofy, długości poszczególnych linii, akcentacji oraz - co już zostało wykazane - symboliki czy zestawu najistotniejszych rekwizytów i motywów), nie będące wszak przekładem sensu stricto (a jedynie produktem przekładopodobnym, okołoprzekładowym), każe mówić o zaistnieniu pewnej międzypoetyki - łączącej zarówno wskazane rysy autora Meditations in an emergency, jak i elementy idiomatyczne dla poezji Sosnowskiego. Z całościowym projektem artystycznym polskiego poety (jeśli można tak nazywać jego twórczość) łączyłaby Cover nie tylko stylistyka marynistyczna, ale i pojawiający się kilkukrotnie konwój, będący wszak składową tytułu tomu, z którego poemat pochodzi (poprzedzając zresztą utwór o tytule Konwój $)^{18}$.

${ }^{18}$ Pisał o tym także Pióro, „Czas to biurokracja, którą tworzą wszyscy”, 108. 
Można oczywiście spierać się o pojęcie tłumaczenia w ogóle, przywołując głosy takie jak te, że każdy przekład poezji jest pisaniem jej od nowa, tłumacz jest autorem tekstu funkcjonującego w języku oryginału, zaś pełna ekwiwalencja nie istnieje i utwór docelowy zawsze zawiera swoisty naddatek (czy, według nastawienia mniej pozytywnego, niedobór) wartości i znaczeń względem tekstu źródłowego. Praktyka tłumaczeniowa pokazuje jednak, że autonomia tłumacza jest - w wielu wypadkach - wyłącznie postulatywna, zaś kategorie takie jak oryginał i kopia czy mimesis wciąż wyznaczają warunki funkcjonowania tekstów tłumaczonych. Wydaje się zatem, że Coveru nie można nazwać przekładem, on sam zresztą - jak zostało już wskazane - do takiego miana nie pretenduje, będąc może jedynie świadectwem fascynacji (zainteresowania, sympatii, niepokoju, ciekawości, przywiązania) poety względem dzieła Franka O’Hary. Cytowani badacze wykazali już także, że trudno byłoby nazwać covery „zwyczajnymi” intertekstami oryginałów - wyraźnie czerpią one pewien twórczy potencjał konkretnych wierszy (poetyk, stylów, fraz, języków) i zaszczepiają go w mowie rodzimej (oraz rodzimej poetyce) ${ }^{19}$. Nie jest to jednak nawiązanie parodystyczne czy odtwórcze (podobnie jak coraz rzadziej definiuje się w kategoriach naśladowania przekład), stąd nie nazwiemy coverów parodiami czy pastiszami. Można mówić natomiast o wchłonięciu istotnych cech poetyki (stylu, obrazowania, nastroju itd.) oraz włączeniu ich do poetyki własnej, co wytwarza swoistą interpoetykę (O’Hary-Sosnowskiego, ale też - chociażby - Johna Ashbery-Sosnowskiego, jak komentuje to bowiem Anna Kałuża, jego poezja, „którą Sosnowski tłumaczył i wprowadził do polskiej literatury, stanowiła pole uzasadnień i uwiarygodnień dla strategii i chwytów poetyckich stosowanych przez autora Życia na Korei”" ${ }^{20}$.

Istnienie owej umiejscowionej między językami interpoetyki - której zbadanie wykracza oczywiście znacznie poza możliwości jednego artykułu - byłoby ciekawe zwłaszcza w kontekście podnoszonej niedawno kwestii uniwersaliów przekładowych ${ }^{21} \mathrm{czy}$ potencjalnego istnienia języka „translationese”, przejawiającego się w charakterystycznym doborze rozwiązań u licznych tłumaczy oraz przenikaniem kalek (czy, mówiąc ogólnie, wzorów) językowych z jednej mowy do drugiej. U Sosnowskiego owo „kalkowanie” angielskiej składni (będące oczywiście celowym zabiegiem artystycznym, nie zaś przekładowym błędem) przejawia się w poemacie przynajmniej kilkukrotnie. „Mój niepokój ma przy sobie broń, ona nie jest biała” jest dokładnym odwzorowaniem szyku „my quietness has a man in it, he’s transparent” (oraz później: „ona jest funkcjonalna, jak eskadra i eskorta, jako desant” w miejsce „he has several likenesses, like stars and years, like numerals"), wraz z utrzymaniem być może nie tyle nienaturalnego, ale rzadko spotykanego powtarzania zaimka „ona”, który w pierwszym cytowanym wersie zamienilibyśmy raczej na neutralne „która”, zaś w drugim - zwyczajnie pominęli. Podobnie rzecz się ma z również już przytaczanym początkiem drugiej części, gdzie podmiot wymienia: „moje dziecko, moje «ja»,/zdeklasowani klasycyści i klasycy. Mój/«smutek tropików» beztroski jak wiatr”. Choć wielokrotne powtarzanie zaimka dzierżawczego nie jest w tym miejscu wyjątkowo nacechowane, warto zauważyć, że nie jest dla

\footnotetext{
${ }^{19} \mathrm{O}$ problematyce intertekstualności w przekładzie pisała Ewa Kraskowska, zob. Ewa Kraskowska, „Intertekstualność a przekład”, w Między tekstami: intertekstualność jako problem poetyki historycznej, red. Jerzy Ziomek, Janusz Sławiński, i Włodzimierz Bolecki (Warszawa: Wydawn. Nauk. PWN, 1992).

${ }^{20}$ Anna Kałuża, „Andrzej Sosnowski”, Polska Poezja Współczesna. Przewodnik encyklopedyczny, udostępniono 19 październik 2019, http://przewodnikpoetycki.amu.edu.pl/encyklopedia/andrzej-sosnowski/.

${ }^{21}$ Ewa Kraskowska, „Uniwersalia przekładowe”, Forum Poetyki, nr 14 (2018): 86-89, http://fp.amu.edu.pl/ uniwersalia-przekladowe/.
} 
polszczyzny charakterystyczne (a więc powiemy na przykład: „chwyć mnie za rękę”, nie zaś „chwyć mnie za moją rękę” - „take my arm”, jak to jest w języku angielskim).

Jednocześnie wydaje się, że owa międzypoetyka dotyczyła będzie nie tylko poziomu tekstowego, a więc ujawniała się wyłącznie na przestrzeni formy, w zakresie środków stylistycznych, konstrukcji utworu, sztafażu symbolicznego itd. Da się ową intertwórczość rozpatrywać także względem problematyki czy struktury głębokiej. Nie sugerując oczywiście, że Sosnowski stał się poetą niepostmodernistycznym i nieznakocentrycznym (jeśli kiedykolwiek takim był) właśnie dzięki lekturze O’Hary (czy jakiejkolwiek innej lekturze), warto zauważyć, jak przejęcie licznych elementów In Memory of My Feelings wpływa na wydźwięk całego poematu. Wyraźne przywiązanie do kwestii tekstowych, widoczne między innymi we fragmentach autotematycznych, zostaje wzbogacone nie tylko przez tło czy podstawę utworu, jakim jest emocjonalny, doświadczeniowy utwór nowojorczyka, ale i przez wprowadzanie nietypowych rozwiązań na przestrzeni samego coveru (a więc egzystencjalne pytania "chodzę i pytam”, obraz podmiotu zamkniętego w łodzi podwodnej i szukającego miejsca, by zarzucić kotwicę itd.), które nie zostają zwyczajnie przepisane, ale (dokładnie w stylu Sosnowskiego) sprowadzone do roli afektywnych tropów (tropów „Ja”, jak chciałby Ryszard Nycz) rozsianych na przestrzeni „mrowia wersów”, wymieszanych z rozmaitymi innymi śladami, rozbijanych ironią czy dowcipem, uniemożliwiających stworzenie jednolitej wykładni Coveru - tak jak i niemożliwe jest stworzenie jednolitej wykładni In Memory of My Feelings. Wytworzone w Coverze miejsca wspólne - także miejsce wspólne dwóch języków, nie będące wszak przekładem - pokazują jednak intrygującą, powstałą na styku wpływów i prądów (post)modernistyczną dyskusję z podmiotowością i tekstualnością, stając się istotnymi głosami w literackiej metarefleksji.

\section{Bibliografia}

Chłopek, Ryszard. „Kogo śmieszy «Cover»?” W Lekcja żywego języka: o poezji Andrzeja Sosnowskiego, zredagowane przez Grzegorz Jankowicz. Kraków: Zielona Sowa : Studium Literacko-Artystyczne przy Instytucie Polonistyki Uniwersytetu Jagiellońskiego, 2003.

Felberg, Karolina. „Melancholia i ekstaza”: projekt totalny w twórczości Andrzeja Sosnowskiego. Warszawa: Instytut Badań Literackich PAN, 2010.

Gutorow, Jacek. „Kilwater”. W Urwany ślad: o wierszach Wirpszy, Karpowicza, Różewicza i Sosnowskiego. Wrocław: Biuro Literackie, 2007.
Kałuża, Anna. „Andrzej Sosnowski”. Polska Poezja Współczesna. Przewodnik encyklopedyczny. Udostępniono 19 październik 2019. http:// przewodnikpoetycki.amu.edu.pl/encyklopedia/andrzej-sosnowski/.

Kraskowska, Ewa. „Intertekstualność a przekład”. W Między tekstami: intertekstualność jako problem poetyki historycznej, zredagowane przez Jerzy Ziomek, Janusz Sławiński, i Włodzimierz Bolecki. Warszawa: Wydawn. Nauk. PWN, 1992.

„Uniwersalia przekładowe”. Forum Poetyki, nr 14 (2018): 86-89. http://fp.amu.edu.pl/ uniwersalia-przekladowe/. 
O’Hara, Frank. „In Memory of My Feelings”. W The Collected Poems of Frank O'Hara, zredagowane przez Donald Allen. Berkeley, Calif.: Univ. of California Press, 1995.

-_- „Pamięci moich uczuć”. Przetłumaczone przez Piotr Sommer. Literatura na Świecie., nr 9-10 (2015): 65-67.

Perloff, Marjorie. Frank O'Hara: Poet among Painters. Chicago: Univ. of Chicago Press, 1997.

Pióro, Tadeusz. „Czas to biurokracja, którą tworzą wszyscy". W Lekcja żywego języka: o poezji Andrzeja Sosnowskiego, zredagowane przez Grzegorz Jankowicz. Kraków: Zielona Sowa : Studium Literacko-Artystyczne przy Instytucie Polonistyki Uniwersytetu Jagiellońskiego, 2003.

„Czytanie poematów O’Hary”. Literatura na Świecie., nr 9-10 (2015): 83-113.

Frank O'Hara and the Ends of Modernism. Warsaw: University of Warsaw. Institute of English Studies, 2013.
Rajewska, Ewa. „Kariera coveru”. W Kultura w stanie przekładu: translatologia - komparatystyka transkulturowość, zredagowane przez Włodzimierz Bolecki i Ewa Kraskowska. Warszawa: Fundacja Akademia Humanistyczna : Instytut Badań Literackich PAN. Wydawnictwo, 2012.

Sendyka, Roma. Od kultury ja do kultury siebie: $o$ zwrotnych formach $w$ projektach tożsamościowych, 2015.

Sosnowski, Andrzej. „Cover”. W Dożynki 19872003. Wrocław: Biuro Literackie, 2006.

Świeściak, Alina. „Melancholia ponowoczesna. Andrzej Sosnowski”. W Melancholia w poezji polskiej po 1989 roku. Kraków: Towarzystwo Autorów i Wydawców Prac Naukowych Universitas, 2010. 


\title{
SEOWA KLUCZOWE:
}

\author{
A N DRZEJ SOS NOWSKI
}

\section{Frank O'Hara}

\author{
przekład literacki
}

m e t a r e f l e k s ja

\section{N T E R P O E T Y KA}

\section{ABSTRAKT:}

Artykuł jest próbą ponownego zinterpretowania poematów In Memory of My Feelings Franka O’Hary oraz Cover Andrzeja Sosnowskiego w świetle ujawnionych w nich wątków autotematycznych. Autorka skupia się najpierw na bliższym zbadaniu relacji, jaka została między owymi tekstami nawiązana, przyglądając się zarówno różnicom (język, emblematy, symbolika, konteksty) oraz podobieństwom, usiłując zbadać, jaki wpływ na utwór Sosnowskiego wywarł poeta szkoły nowojorskiej. Później natomiast uwaga zostaje zwrócona na wytworzenie między dziełami swoistej przestrzeni zależności - tekst dyskutuje możliwość rozpatrywania wiersza Sosnowskiego w kategoriach interpoetyki. 


\section{autotematyzm}

I N T E R T E K S T U A L N O Ś Ć

translatologia

\section{NOTA O AUTORZE:}

Agnieszka Waligóra - ur. 1995, magister, doktorantka na Wydziale Filologii Polskiej i Klasycznej na Uniwersytecie im. Adama Mickiewicza w Poznaniu. Jej zainteresowania badawcze koncentrują się wokół polskiej poezji najnowszej i jej kontekstów teoretycznych, filozoficznych i politycznych. Wybrane publikacje: Finat „Imiesłowów”. Interpretacja wiersza [*** Razić, urazić, porazić, wrazić...] Krystyny Miłobędzkiej, w: Laboratorium poezji kobiecej XX wieku, red. J. Grądziel-Wójcik, J. Kaniewski, A. Kwiatkowska, T. Umerle, Poznań 2015; Poeta i pismo. O dwóch utworach Stanisława Barańczaka, w: Ścieżki interpretacji. Szkice nie tylko o poezji, red. J. Grądziel-Wójcik, A. Kwiatkowska, Poznań 2017; Poezja anestetyczna. „nice” Barbary Klickiej, „Poznańskie Studia Polonistyczne. Seria Literacka" 2018, nr 33; Polska poezja najnowsza wobec Holokaustu, w: Work in progress. Konfrontacje trzeciego pokolenia po Zagładzie, red. J. Budzik, Kraków 2018. 